\title{
CANCER UKA.
}

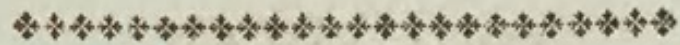

CHARACTER GENERICUS.

Pedes octo (rarius sex aut decem;) insuper manus dua chelatæ.

Oculi duo, distantes, plurimis pedunculati; elongati, mobiles.

Cauda articulata, inermis.

CHARACTER SPECIFICUS, छ̈C.

CANCER subquadratus luteus chela dextra maxima.

CANCER UKA una. Seb.mus. 3. t. 18. f. s. CANCER UKA? Lin. Syst. Nat.

Hujus speciei descriptionem a celeberrimo Sebæ thesauro in opus nostrum transferre non dubitavimus. "Cancer Uka ura Brasiliæ incolis sic vocatur, quia in paluciibus et rivis vivit. Corpus ejus breve est, oblongo-latum, scutiforme, saturate flavescens. Pes anticus dextri lateris forcipes gerit quam vastissimos; perpusillos contra sinister : ut nimirum horum ope in os queat ingeri, quod majoribus illis arreptum est ; siquidem hi adeo intorqueri nequeant. Pateat ergo rursus supremi conditoris sapientia creatis singulis quam benignissime prospiciens. Supra os binæ cernuntur vaginulæ longiuscula, in quibus globuli, tanquam capitula acicularum, hrerent, oculorum munere fungentes, qui hinc ad utrumque latus longum emitti possunt et undequaque dispicere, rursumque subito sub testa recondi, si quid occurrat periculi, ne ab allisu lædantur. Octo reliqui peries e tribus singuli constant articulis, computatis simul unguibus; primoresque articuli tantum pilosi sunt. Cauda perparva est et angusta. Subtus dilute cinerea regnat flavedo." 


\section{UKA CRAB.}

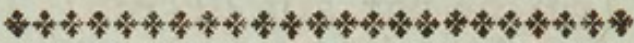

\section{GENERIC CHARACTER.}

Legs generally eight; (in some species six or ten, besides two claspers or chelated arms.) Eyes two, commonly distant; footstalked, moveable.

Tail articulated.

\section{SPECIFIC CHARACTER, EंC.}

Squarish yellow $\mathrm{CRAB}$ with the claw on the right side extremely large.

UKA CRAB.

UKA UNA.

Seba. 3. t. 18. f. 8 .

This species is taken from the work of Seba, who informs us that it is called by the Brasilians by the name of Ula una, from its frequenting marshes and rivulets. Its general colour is deep yellow on the upper parts, and pale gieyish yellow beneath: it is chiefly remarkable for the very large size of its right claw which is calculated for seizing its prey, while the left, which is small and slender, is formed for conveying the food to its mouth : the eyes are small, and situated on long, moveable footstalks, and are. capable of being occasionally retracted under the shell, the tail is very small and slender. 



\section{$2 \mathrm{BHL}$ Biodiversity Heritage Library}

Shaw, George. 1803. "The Uka Crab, Cancer uka [PI. 588]." The Naturalist's Miscellany 14(CLXVIII), https://doi.org/10.5962/p.311031.

View This Item Online: https://www.biodiversitylibrary.org/item/278723

DOI: https://doi.org/10.5962/p.311031

Permalink: https://www.biodiversitylibrary.org/partpdf/311031

\section{Holding Institution}

Museums Victoria

\section{Sponsored by}

Atlas of Living Australia

\section{Copyright \& Reuse}

Copyright Status: Public domain. The BHL considers that this work is no longer under copyright protection.

This document was created from content at the Biodiversity Heritage Library, the world's largest open access digital library for biodiversity literature and archives. Visit BHL at https://www.biodiversitylibrary.org. 